\title{
IDENTIFIKASI IRIS MENGGUNAKAN IMPROVED LEVENBERG-MARQUARDT
}

\author{
Rocky Yefrenes Dillak
}

\begin{abstract}
Abstrak :
Sistem biometrika adalah suatu sistem pengenalan diri menggunakan bagian tubuh atau perilaku manusia seperti sidik jari, telapak tangan, telinga, retina, iris mata, wajah, suhu tubuh, tanda tangan, dll. Iris mata merupakan salah satu biometrika yang sangat stabil, handal, akurat dan merupakan metode autentikasi biometrika tercepat oleh karena itu merupakan suatu topik penelitian yang sangat diminati oleh banyak peneliti. Penelitian ini bertujuan untuk mengembangkan suatu metode yang dapat digunakan untuk mengidentifikasi secara otomatis seseorang berdasarkan citra iris mata miliknya menggunakan jaringan syaraf tiruan levenberg-marquardt. Penelitian ini menggunakan metode deteksi tepi cany dan circular hough transform untuk segmentasi wilayah iris yang terletak diantara pupil dan sclera serta metode ekstraksi ciri gray level cooccurence matrix (GLCM) yang digunakan untuk ekstraksi ciri. Ciri-ciri tersebut adalah maximum probability, correlation, contrast, energy, homogeneity, dan entropy. Ciri-ciri tersebut kemudian dilatih menggunakan jaringan syaraf tiruan dengan aturan pembelajaran levenberg-marquardt algorithm untuk mengidentifikasi seseorang berdasarkan citra irisnya. Penelitian ini menggunakan 150 data citra iris yang masing-masing terbagi atas 100 data citra iris untuk pelatihan dan 50 data citra iris untuk pengujian. Berdasarkan hasil pengujian yang dilakukan diperoleh correct recognition rate (CRR) sebesar 99.98\% yang menunjukkan bahwa metode ini dapat digunakan untuk mengidentifikasi secara otomatis seseorang berdasarkan citra iris mata miliknya.
\end{abstract}

Kata Kunci : identifikasi iris mata, sistem biometrika, GLCM, jaringan syaraf tiruan, levenberg-marquardt algorithm

\section{PENDAHULUAN}

Informasi yang terkandung dalam semua sistem biometrika sangat tergantung pada bentuk yang bervariasi secara acak yang dimiliki diantara manusia [Daugman, 2002]. Hal ini sangat berbeda dengan identifikasi personal sistem keamanan biometrik tidak membutuhkan password yang dibuat atau diberikan orang lain tetapi menggunakan pengukuran biometrik milik individu seperti sidik jari, geometri tangan, dan iris sehingga kemungkinan dicuri, hilang, dilupakan, atau dipalsukan sangat kecil [Zhou, 2009]. Perbandingan dari berbagai sistem pengenalan biometrik menunjukkan bahwa sistem pengenalan iris sangat stabil, handal, tepat, dan merupakan metode autentikasi biometrik tercepat [Tiwari, dkk., 2012]. Tujuan dari pengenalan iris sebagai teknologi berbasis biometrik untuk identifikasi manusia dan verifikasi adalah untuk mengenali seseorang dari cetak irisnya [Kayte, dkk., 2012]. Sebagai suatu biometrika iris memiliki beberapa kelebihan : 
- Iris mata bebas dari pengaruh genetik sehingga tidak ada iris mata yang sama sekalipun iris kiri dan kanan milik orang yang sama atau iris mata milik kembar identik [Daugman, 1993 ; Mohamed, et al., 2009 ; Gopikrishnan and Santhanam, 2010].

- Posisi iris mata yang dilindungi oleh kornea dan aqueous humor sehingga sulit atau sangat tidak mungkin mengalami kerusakan [Harjoko, et al., 2009].

- Iris mata manusia tidak berubah dan bersifat stabil mulai usia satu tahun sampai meninggal [Chaudhary and Mubarak, 2012].

Iris mata selain memiliki kelebihan sebagaimana telah diuraikan diatas, juga memiliki beberapa kelemahan sebagai suatu biometrika meliputi :

- Sulit untuk menangkap citra iris oleh karena ukurannya yang sangat kecil [Roy, 2011]

- Pada bagian tertentu iris dihalangi oleh kelopak atas dan bawah dan tertutup oleh bulumata, pantulan, dan lensa [Makthal, 2005]

- Sebagaimana ukuran pupil berubah-ubah, perubahan bentuk non elastis adalah kelemahan lainnya [Makthal, 2005].

Kebutuhan akan akurasi identifikasi manusia telah berkembang dari waktu-ke waktu untuk tujuan keamanan dan pemeriksaan identitas [Khan, et al., 2012). Gangguan bulu mata dan kelopak mata merupakan masalah yang paling sering muncul dalam sistem pengenalan iris dikarenakan keduanya merupakan bagian dari mata sama seperti iris, sehingga diperlukan pemilihan wilayah iris yang tidak rentan terhadap gangguan bulu mata dan kelopak mata. Adanya gangguan bulu mata dapat mempengaruhi akurasi sistem identifikasi iris. Menurut Daugman [1993] dan Ezhilararasan, et al., [2010] informasi pola iris tersebar secara acak dan tidak merata pada wilayah iris, tetapi perlu diketahui bahwa terdapat karakteristik iris yang terkonsentrasi pada wilayah dekat pupil. Oleh karena itu pengenalan iris yang baik dapat diperoleh dengan hanya menganalisis $50 \%$ atau kurang dari wilayah iris yang tersedia. Hal ini didukung oleh penelitian yang dilakukan oleh Vatsa, et al., [2008] yang menggunakan sebagian wilayah iris yaitu bagian kiri dan bagian kanan, Gopikrishnan and Santhanam [2011] dalam penelitiannya menggunakan $1 / 4$ ukuran iris untuk mempercepat image processing. Murugan and Savithiri [2010], Savithiri and Murugan [2011], Murugan and Savithiri [2011] dalam penelitian mereka membagi wilayah iris dalam empat kategori yaitu internal region, external region, lower region dan upper region. Hasil penelitian mereka menunjukkan hasil yang baik namun pemilihan wilayah tersebut masih rentan terhadap gangguan bulu mata dan kelopak mata. Oleh karena itu dalam penelitian ini penulis akan menggunakan pendekatan menggunakan wilayah iris yang merupakan irisan internal region dan lower region untuk meminimalisasi gangguan bulu mata dalam proses identifikasi iris.

Berdasarkan latar belakang tersebut di atas, penelitian ini akan mengkaji pengaruh pemakaian wilayah iris yang merupakan irisan internal region dan lower region untuk proses indentifikasi iris dengan algoritma jaringan syaraf tiruan levenberg-marquardt.

Penelitian ini bertujuan untuk mengembangkan suatu metode yang dapat digunakan untuk melakukan identifikasi iris menggunakan jaringan syaraf tiruan levenbergmarquardt algorithm. Manfaat penelitian ini adalah untuk menghasilkan suatu metode yang dapat digunakan untuk melakukan identifikasi personal berdasarkan citra irisnya. Penelitian ini juga diharapkan memberikan informasi bagi penelitian lanjutan tentang biometrika menggunakan citra iris.

\section{TINJAUAN PUSTAKA}

Penelitian tentang iris mata manusia sudah banyak dilakukan oleh para peneliti, seperti penelitian tentang deteksi kolestrol, deteksi ginjal, identifikasi iris, dll.

Penggunaan sebagian wilayah iris dalam proses pengenalan iris telah banyak dilakukan dan menunjukkan hasil yang baik seperti yang dilakukan oleh Ezhilarasan, et al., [2010] yang melakukan penelitian tentang pengenalan iris berdasarkan pola tekstur iris. Gausian 


\section{Jurnal Ilmiah FLASH Volume 1 Nomor 1 Desember 2015}

smoothing digunakan pada citra inputan dengan tujuan untuk menghilangkan noise setelah itu dilakukan segmentasi iris menggunakan metode integro-diferential operator. Penelitian ini diusulkan berdasarkan pada kenyataan bahwa wilayah yang mengandung paling banyak informasi tentang iris adalah wilayah yang mendekati pupil, dengan demikian tidak semua bagian iris akan diekstrak cirinya melainkan dipilih bagian yang dianggap paling represtative yaitu inner multi-bands. Selanjutnya hasil segmentasi iris dinormalisasikan menggunakan Daugman's rubber sheet. Selajutnya dilakukan pencocokan data iris menggunakan HD dan CASIA v1 dan CASIA v2 datasheet digunakan untuk validasi sistem yang mencapai tingkat akurasi $99,50 \%$ dan menghemat waktu komputasi. Penelitian serupa dilakukan oleh Murugan and Savihitri [2011] yang merepresentasikan sistem pengenalan iris berdasarkan bagian-bagian dari pola iris menggunakan BPNN. Penelitian ini bertujuan untuk menemukan sistem pengenalan iris yang handal dan efisien. Pola iris disegmentasi menggunakan metode Daugman's IntegroDifferential Operator, hasil segmentasi iris dinormalisasi menggunakan local histogram analysis selanjutnya dilakukan ekstrasi ciri dari wilayah iris yaitu Fully Iris Template, Inner Region, Outer Region, Lower Region, Upper Region menggunakan 3 (tiga) metode ekstrasi ciri yaitu Gabor Wavelet (GW), Local Binary Pattern (LBP), Histogram of Oriented Gradient (HOG) kemudian pola iris diidentifikasi menggunakan Backpropagation Neural Network (BPNN). Hasil penelitian menunjukkan performance sistem yang sangat baik dimana akurasi sistem mencapai $100 \%$ untuk ketiga metode ekstrasi ciri berdasarkan pada pola iris yang disegmentasi pada bagian bawah iris (lower region). Gopikrishnan dan Santhanam (2011) juga melakukan penelitian menggunakan Pola iris yang ukurannya telah dikurangi $1 / 4$ dari ukuran sebenarnya dan menggunakan beberapa Classifier yaitu HD, Cascade Forward BP, Feed Forward BP, Elman Forward BP dan Perceptron. Pengurangan ukuran iris mata dilakukan berdasarkan kesimpulan dari penelitian yang dilakukan oleh Du, et al., [2005] bahwa partial iris portion dari pola iris menggambarkan keunikan dan pupil tidak memiliki efek langsung pada akurasi identifikasi dan pengenalan biometrika. Penelitian ini bertujuan untuk meningkatkan kecepatan dan akurasi sistem identifikasi dan pengenalan biometrika pola iris mata manusia menggunakan neural network. Data yang digunakan adalah CASIA dataset. Lokasi pupil, kelopak atas dan kelopak bawah ditentukan pertama kali menggunakan metode deteksi tepi canny namun sebelumnya ukuran citra iris telah direduksi menjadi $1 / 4$ dari ukuran asli dengan tujuan untuk meningkatkan performance sistem. Metode Hough Transfrom digunakan untuk mencari titik tengah dan radius pupil selanjutnya menentukan batas atas dan bawah iris menggunakan horizontal sobel filter. Hasil dari penelitian menunjukkan bawah perceptron memiliki performance yang lebih baik dibandingkan dengan metode yang lain. Berdasarkan uraian diatas menunjukkan bahwa penelitian menggunakan internal region [Ezhilarasan, 2010] dan lower region [Murugan and Savithiri, 2011] memberikan hasil yang sangat baik, Meskipun akurasi yang diperoleh sangat baik namun pemilihan ROI iris oleh beberapa peneliti sebagaimana diuraikan diatas masih mempunyai kemungkinan terganggu dengan bulu mata dan kelopak mata sehingga peneliti akan menggunakan pendekatan irisan internal region dan lower region dimana wilayah tersebut tidak rentan dengan gangguan bulumata dan kelopak mata dan belum ada peneliti yang menggunakan wilayah tersebut dalam penelitian mereka.

Pengenalan iris secara otomatis telah banyak dilakukan menggunakan machine learning seperti yang dilakukan oleh Chowhan and Shinde [2011] yang bertujuan untuk mengembangkan sistem identifikasi biometrika menggunakan iris. Proses pengenalan iris dilakukan menggunakan Fuzzy Min-Max Neural Network yang mencapai tingkat pengenalan sebesar 95,68\%. Farouk, et al., [2011] 
memperkenalkan suatu pendekatan yang baru dan efektive untuk pengenalan iris yang dioperasikan menggunakan active contour models untuk preprocessing dan segmentasi, $2 D$ Gabor Wavelet untuk ekstrasi ciri, dan MDANN untuk pencocokan. Penelitian ini menggunakan data uji CASIA V-3 yang terdiri dari 1992 citra iris dari 249 kelas yang berbeda dan database UBIRIS yang terdiri dari 1205 citra iris dari 241 orang, namun tidak semua data tersebut digunakan karena terjadi kegagalan pada tahap segmentasi iris masing-masing CASIA v3 $=81$ citra iris dan UBIRIS $=34$ citra iris. Pengujian dilakukan dalam dua mode yaitu mode verifikasi menggunakan FMR, FNMR, FAR, FRR dan mode identifikasi menggunakan CRR. Hasil pengujian menunjukkan CRR $=99,25 \%$. Rashad, et al., [2011] melakukan penelitian yang bertujuan untuk mengembangkan suatu algoritma baru menggunakan LBP dan Histogram properties (pendekatan statisitk) untuk ekstraksi fitur dan combine LVQ Classifier (pendekatan neural network) untuk klasifikasi. Metode ini diharapkan dapat menghasilkan akurasi yang baik dalam pengenalan iris. Metode segmentasi iris yang digunakan adalah Canny Edge Detection dan Hough Transformation selanjutnya dinormalisasi menggunakan metode Daugman's Rubber Sheet. Hasil penelitian ini menunjukan performance dengan tingkat akurasi yang tinggi sebesar 99,87\% menggunakan database CASIA, MMU1, MMU2, dan LEI. Penelitian serupa dilakukan oleh Chaudhary and Mubarak [2012] menggunakan rectangular area method untuk lokalisasi iris dan JST Backpropagation untuk pengenalan iris dengan tingkat pengenalan iris mencapai 99,25\%.Penelitian serupa dilakukan oleh Hossain and Sarma [2012] yang memperkenalkan suatu sistem pengenalan iris yang handal menggunakan 2D-Discrete Cosine Transform (DCT) untuk ekstrasi ciri dan Self Organizing Map Artificial Neural Network (SOM/ANN) untuk klasifikasi citra iris. Sistem bekerja secara efisien menggunakan 49-100
DCT coefficient dan mencapai akurasi sekitar 99.1\% pada epochs ke 1000 lebih baik dibandingkan dengan menggunakan Radial Basis Function Artificial Neural Network (RBF/ ANN) dalam penelitian mereka sebelumnya.

\section{METODE PENELITIAN}

\subsection{Rancangan Arsitektur Sistem}

Peneliti mengusulkan arsitektur sistem seperti Gambar 1. Penjelasan pada sub-bab berikut memaparkan dengan lebih detail proses yang terjadi dalam setiap bagiannya

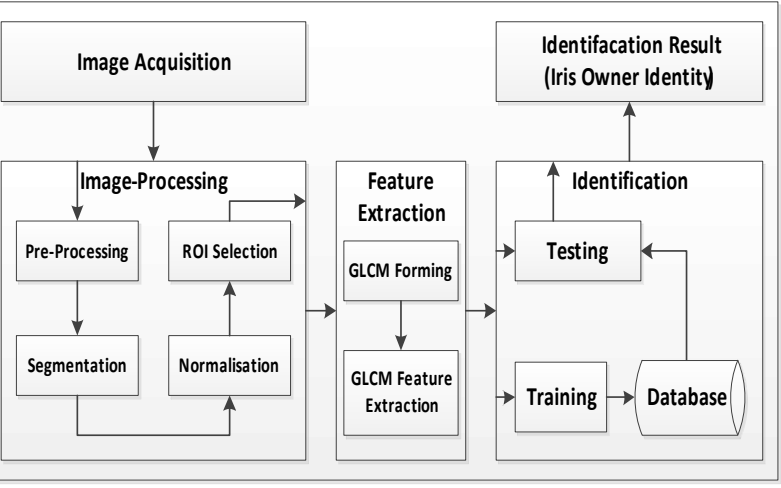

Gambar 1. Arsitektur sistem klasifikasi fase retinopati diabetes

\subsection{Image Processing}

Bertujuan untuk memperbaiki kualitas citra, menemukan lokasi iris, menentukan zona perhitungan yaitu daerah diantara luar pupil dan di dalam sclera serta menghasilkan citra iris yang lebih baik untuk digunakan pada tahap selanjutnya. Tahapan Image-processing yang dilakukan meliputi tahap preprocessing, segmentation, normalisation, ROI selection.

\subsubsection{Preprosesing}

Tujuan utama dari preprosesing citra adalah untuk meningkatkan kualitas citra dimana citra yang dihasilkan dapat memberikan informasi yang lebih jelas bagi manusia sehingga memudahkan dalam melakukan interpretasi atas suatu citra [Kuivaleinen, 2005]. Dalam penelitian ini digunakan dua teknik preprosesing sebagai berikut : 


\section{Jurnal Ilmiah FLASH Volume 1 Nomor 1 Desember 2015}

\section{Gausian Filter.}

Sebelum dilakukan segmentasi citra iris maka sebelumnya dilakukan perbaikan kualitas citra menggunkan filter gausian yang bertujuan untuk menghilangkan noise. Berikut adalah fungsi matematika dari filter gausian :

$$
g(x, y)=\frac{1}{2 \pi \sigma^{2}} e^{\frac{x^{2}+y^{2}}{2 \sigma^{2}}}
$$

Dengan $\mathrm{g}(\mathrm{x}, \mathrm{y})$ menyatakan titik tengah dari fungsi gausian, $\sigma$ adalah standard deviasi dari distribusi gausian dan $\pi$ adalah radius dari koordinat polar.

\section{Operasi Morpholgi.}

Operasi morfologi yang digunakan adalah operasi opening yang bertujuan untuk menekan / menyembunyikan gangguan dari bulu mata. Operasi opening merupakan kebalikan dari operasi closing yaitu operasi erosi yang diikuti dengan dilasi menggunakan elemen penstruktur yang sama. Secara matematika, operasi opening dinyatakan dengan :

$$
A o B=(A \Theta B) \oplus B
$$

Dimana A merupakan citra yang akan diperbaiki dan B merupakan elemen penstruktur A.

\subsubsection{Segmentation}

Proses segmentasi adalah proses untuk memisahkan obyek dari background, dalam hal ini untuk memisahkan wilayah iris dari pupil dan sclera. Dalam penelitian ini metode segmentasi yang digunakan adalah metode circular hough transform dan canny edge detection untuk proses segmentasi wilayah iris yang akan digunakan untuk identifikasi iris terhadap citra inputan.

\subsubsection{Normalisation}

Ukuran iris yang diambil dengan kamera/ alat sensor iris mata dari orang yang berbeda bahkan dari orang yang sama dapat berbedabeda hal ini disebabkan oleh variasi pencahayaan dan faktor-faktor lain seperti deformasi elastis tekstur iris yang sangat mempengaruhi hasil pencocokan. Oleh karena itu dilakukan normalisasi ukuran citra iris menggunakan model daugman rubber sheet [Daugman,2009] agar ukuran citra iris menjadi seragam. Citra iris akan ditransformasi ke bentuk segiempat seperti ditunjukkan pada Gambar 2.

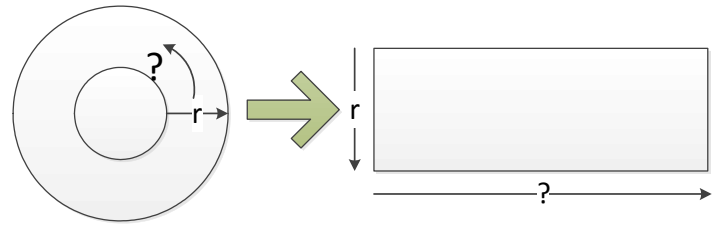

Gambar 2. Daugman's rubber sheet model

Remmaping wilayah iris dari $(\mathrm{x}, \mathrm{y})$ koordinat kartesian ke koordinat polar direpresntasikan sebagai berikut :

$I(x(r, \theta), y(r, \theta)) \rightarrow I(r, \theta)$

$x(r, \theta)=(I-r) x_{p}(\theta)+r x_{1}(\theta)$

$x(r, \theta)=(I-r) x_{p}(\theta)+r y_{1}(\theta)$

Dimana $\mathrm{I}(\mathrm{x}, \mathrm{y})$ adalah iris region image, $(\mathrm{x}, \mathrm{y})$ adalah koordinat Cartesian, $(r, \theta)$ adalah koordinat polar, dan koordinat batas pupil dan batas iris sepanjang arah $\theta$.

\subsubsection{ROI Selection}

Setelah dilakukan proses normalisasi ukuran citra iris maka dilakukan pemilihan ROI dari citra iris yang merupakan wilayah irisan dari internal region dan lower region.

\subsubsection{Pembentukan GLCM}

Penelitian ini menggunakan GLCM multi arah (multiple) yang dibentuk menggunakan jarak 2 pixel tetangga $(\mathrm{d}=2)$. Jarak 2 pixel tetangga dipilih karena termasuk 
salah satu jarak ideal dalam membentuk GLCM [Gadkari, 2004]. Langkah - langkah membentuk multiple GLCM dalam penelitian ini sebagai berikut :

1. Tetapkan jarak pixel (d) yang diinginkan.

2. Hitung semua arah yang mungkin.

3. Bentuk GLCM untuk setiap arah (menggunakan langkah - langkah membentuk GLCM ).

4. Hitung semua ciri statistik untuk setiap arah yang terbentuk.

5. Hitung rata - rata (mean) dari setiap ciri pada semua arah yang terbentuk.

Jumlah arah yang terbentuk pada distance $\mathrm{d}=2$ adalah 16 , artinya terdapat 16 GLCM yang terbentuk $\left(\mathrm{M}_{1}\right.$ sampai $\left.\mathrm{M}_{16}\right)$.

\subsubsection{Ekstraksi ciri GLCM}

Setelah GLCM terbentuk pada suatu jarak dan arah tertentu, maka langkah selanjutnya adalah menghitung ciri statistik dari semua GLCM yang telah terbentuk berdasarkan jarak dan arah yang telah terbentuk. Enam elemen yang diusulkan oleh Gadkari [2004] adalah : (i) maximum probability, (ii) entropi, (iii) energy, (iv) korelasi, (v) kontras, dan (vi) homogenitas. Proses ektraksi ciri dilakukan dengan menghitung 6 ciri statistik dari setiap GLCM (16 GLCM) sebagai berikut :

1. Max Probability $=\max \left(p_{i j}\right)$

2. Entropi.

Entropi menunjukan ukuran ketidakteraturan distribusi intesitas suatu citra pada matriks co-coccurence. Persamaannya untuk menghitung entropi adalah:

Entopi $=-\sum_{i=1}^{k} \sum_{j=1}^{k} p_{i j} \log _{2} p_{i j}$

3. Energi.

Energi adalah fitur untuk mengukur konsentrasi pasangan intensitas pada matriks co-occurance [Gonzales and Woods, 2008]. Nilai energi akan makin membesar bila pasangan piksel yang memenuhi syarat matriks intensitas cooccurance terkonsentrasi pada beberapa koordinat dan mengecil bila letaknya menyebar. yang digunakan untuk menghitung energi adalah :

Energi $=\sum_{i=1}^{k} \sum_{j=1}^{k} p_{i j}^{2}$

4. Korelasi.

Ciri ini menunjukan tingkat korelasi antar pixel dalam suatu citra. Persamaannya adalah :

Korelasi $=\sum_{i=1}^{k} \sum_{j=1}^{k} \frac{\left(\mathrm{i}-\mathrm{m}_{\mathrm{r}}\right)\left(j-m_{c}\right) p_{i j}}{\sigma_{r} \sigma_{c}}$

\section{Kontras}

Kontras adalah fitur yang digunakan untuk mengukur kekuatan perbedaan intensitas dalam citra [Gonzales and Woods, 2008]. Nilai kontras membesar jika variasi intensitas citra tinggi dan menurun bila variasi rendah. Persamaan yang digunakan untuk mengukur kontras suatu citra ditunjukkan pada persamaan di bawah ini :

Kontras $=\sum_{i=1}^{k} \sum_{j=1}^{k}(i-j)^{2} p_{i j}$

6. Homogenitas

Homogenitas digunakan untuk mengukur kehomogenan variasi intensitas citra [Gonzales and Woods, 2008]. Nilai homogenitas akan semakin membesar bila variasi intensitas dalam citra mengecil. Homogenitas dihitung dengan persamaan di bawah ini :

Homogenitas $=\sum_{i=1}^{k} \sum_{j=1}^{k} \frac{p_{i j}}{1+|i-j|}$

Untuk melakukan identifikasii terhadap citra iris, maka hasil proses ektraksi ciri statistik selanjutnya akan dijadikan sebagai data masukan untuk dilatih dengan jaringan syaraf tiruan (JST) untuk mengenali pola inputan serta pasangan pola outputnya. 


\subsubsection{Pelatihan jaringan syaraf tiruan levenberg-marquardt}

Proses pelatihan jaringan pada dasarnya merupakan proses penyesuaian bobot-bobot untuk masing - masing simpul antara lapisan input, lapisan tersembunyi, dan lapisan output. Penyesuaian bobot dilakukan secara terusmenerus sampai dicapai error yang paling minimum [Dilak and Bintiri, 2012 ; Dilak et al., 2012]. Fungsi aktivasi yang digunakan adalah fungsi aktivasi tangent hyperbolic. Arsitektur JST yang digunakan dalam penelitian ini seperti ditunjukkan pada Gambar 2.

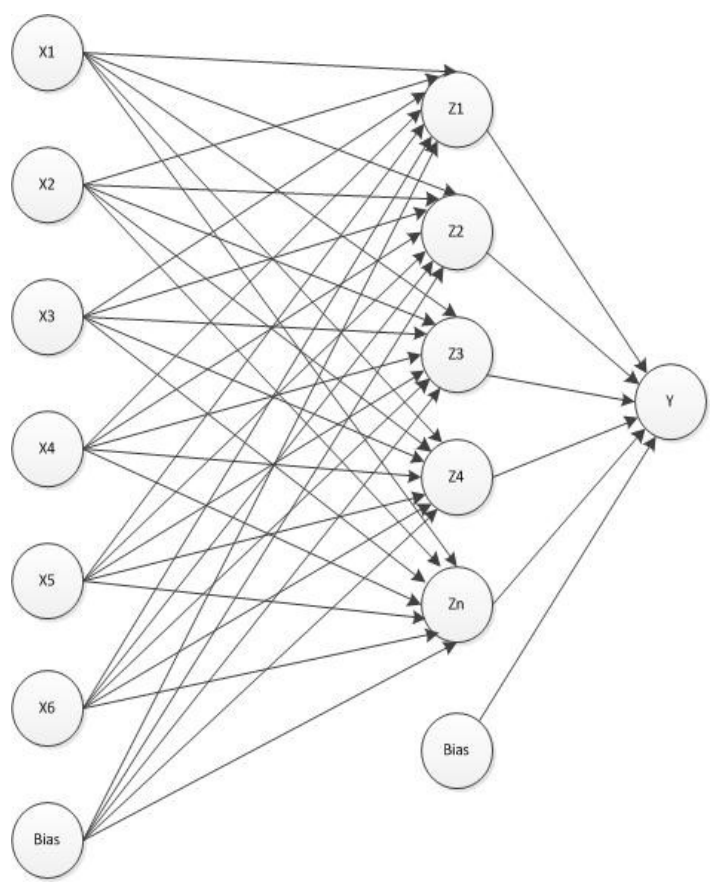

Gambar 3. Arsitektur JST

- Data input yang digunakan sebagai pola dalam pelatihan JST sebanyak 6 buah yang terdiri atas 6 buah ciri statistik dan bias. Data inputan tersebut adalah :

$\mathrm{x} 1$ = maximum probability

$\mathrm{x} 2=$ correlation

$\mathrm{x} 3=$ contrast

$\mathrm{x} 4=$ energy

$\mathrm{x} 5$ = entropy

$\mathrm{x} 6$ = hommogeneity

$\mathrm{x} 7=$ bias
- Jumlah hidden layer : 1 lapisan tersembunyi, dengan jumlah neuron dalam lapisan tersembunyi divariasikan antara 5 - 7 neuron pada setiap hidden layer.

- Jumlah neuron dalam lapisan output sebanyak 1 neuron.

Algoritma Levenberg-Marquardt merupakan pengembangan algoritma backpropagation stándar. Pada algoritma backpropagation, proses update bobot dan bias menggunakan negative gradient descent secara langsung sedangkan algoritma levenbergmarquardt menggunakan pendekatan matrik Hesian $(\mathrm{H})[16]$ yang dapat dihitung dengan,

$H=J^{T} e$

Sedangkan gradient dapat dihitung dengan,

$g=J^{T} J$

Dalam hal ini $\mathrm{J}$ merupakan sebuah mattrik jacobian yang berisikan turunan pertama dari error jaringan terhadap bobot dan bias jaringan. Perubahan pembobot dapat dihitung dengan,

$\Delta X=\left[J^{T} J+\mu I\right]-J^{T} e$

Sehingga perbaikan pembobot dapat ditentukan dengan,

$$
\begin{aligned}
& X=X+\Delta X \\
& X=\Delta X+\left[J^{T} J+\mu I\right]-J^{T} e
\end{aligned}
$$

$$
\left[\begin{array}{ccccc}
\frac{\partial e_{11}(x)}{\partial x_{1}} & \frac{\partial e_{11}(x)}{\partial x_{2}} & \frac{\partial e_{11}(x)}{\partial x_{3}} & \ldots & \frac{\partial e_{11}(x)}{\partial x_{n}} \\
\frac{\partial e_{k 1}(x)}{\partial x_{1}} & \frac{\partial e_{k 2}(x)}{\partial x_{2}} & \frac{\partial e_{k 1}(x)}{\partial x_{2}} & \cdots & \frac{\partial e_{k 1}(x)}{\partial x_{n}} \\
\frac{\partial e_{12}(x)}{\partial x_{1}} & \frac{\partial e_{12}(x)}{\partial x_{2}} & \frac{\partial e_{12}(x)}{\partial x_{3}} & \ldots & \frac{\partial e_{k 2}(x)}{\partial x_{n}} \\
\frac{\partial e_{k 2}(x)}{\partial x_{1}} & \frac{\partial e_{k 2}(x)}{\partial x_{2}} & \frac{\partial e_{k 2}}{\partial x_{3}} & \cdots & \frac{\partial e_{k 2}}{\partial x_{n}} \\
\ldots & \ldots & \ldots & \ldots & \cdots \\
\frac{\partial e_{k p}(x)}{\partial x_{1}} & \frac{\partial e_{k p}}{\partial x_{2}} & \frac{\partial e_{k p}}{\partial x_{3}} & \ldots & \frac{\partial e_{k p}}{\partial x n}
\end{array}\right]
$$


Dimana :

$\mathrm{X}=$ fungsi bobot-bobot jaringan dan bias

$\mathrm{X}=\left[v_{11}, v_{12}, . ., v_{i j} ; v_{01}, v_{02}, . . v_{0 j} ; w_{11}, w_{j k} ; w_{01}, w_{02}, . . w_{o K}\right]$

$\mathrm{E}$ adalah vektor yang menyatakan semua error pada output jaringan

$e=\left[t_{1}-y_{1} t_{2}-y_{2} \ldots t_{p}-y_{p}\right]^{T}$

$\mu=$ konstant learning

$\mathrm{I}=$ matrik identitas

Algoritma pelatihan Jaringan Syaraf Tiruan Levenberg-Marquardt seperti ditunjukkan pada Gambar 4.

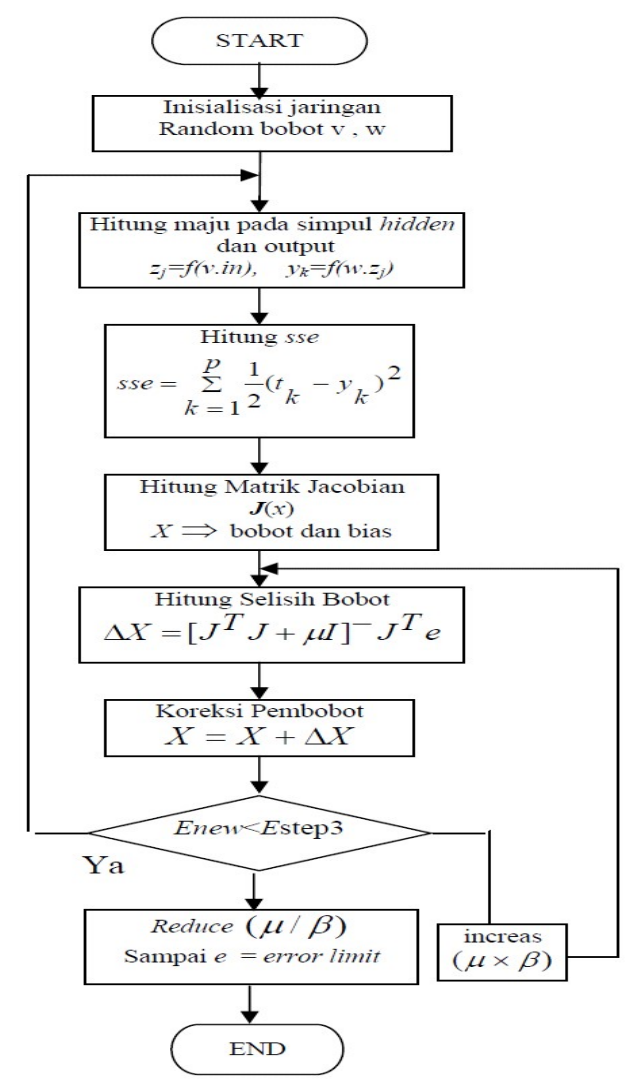

Gambar 4. Pelatihan JST/LM

\subsubsection{Pengujian jaringan syaraf tiruan levenberg-marquardt}

Setelah JST dilatih dengan sekumpulan pola maka tahap selanjutnya adalah melakukan pengujian terhadap kinerja dari JST sekaligus untuk mengukur kinerja dari sistem yang dibangun. Algoritma pengujian jaringan syaraf tiruan mengikuti flowchart seperti Gambar 5.

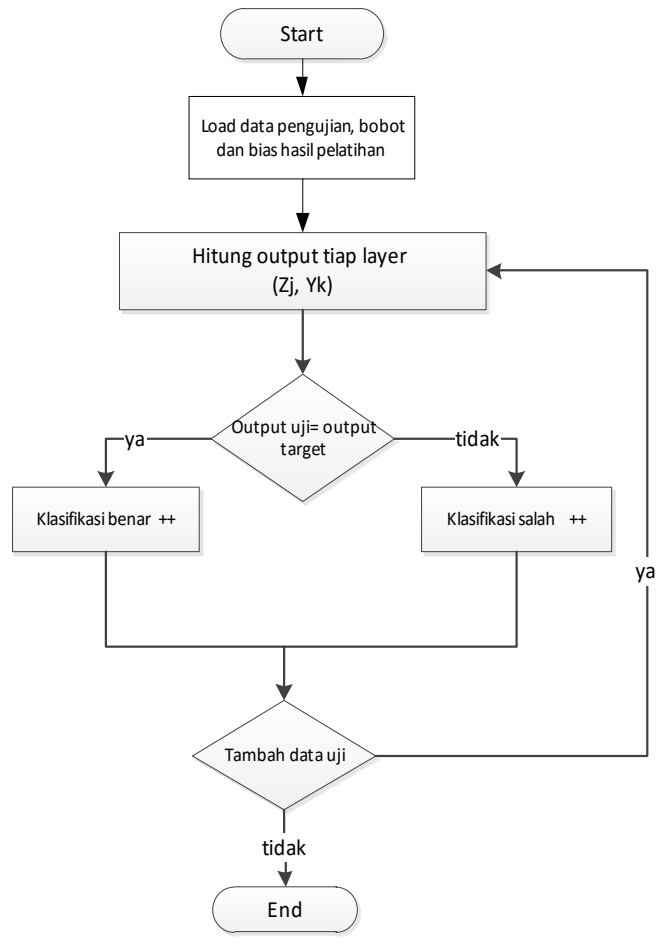

Gambar 5. Pengujian JST

\section{HASIL DAN PEMBAHASAN}

Pada penelitian ini, pengujian dilakukan dengan melatih JST secara berulang-ulang untuk mendapatkan bobot-bobot jaringan yang optimal sehingga dapat digunakan untuk menyelesaikan permasalahan klasifikasi. Data yang digunakan dalam penelitian ini berjumlah 100 citra terbagi atas dua kelompok data yakni:

- Data pelatihan 100 citra

- Data pengujian 50 citra.

Data - data tersebut diekstrak menggunakan metode GLCM dengan jarak 2 pixel tetangga. Parameter JST yang digunakan dalam pengujian ini adalah sebagai berikut :

- Learning rate $(\alpha)=0.1$.

- Momentum $(\mu)=0.9$.

- Jumlah lapisan tersembunyi = 1 lapis.

- Jumlah neuron dalam lapis tersembunyi $=5$.

- Batas toleransi error =0,001 


\subsection{Pengujian Akurasi Kinerja JST Levenberg-Marquardt}

Kinerja JST dalam mengidentifikasi seseorang berdasarkan citra irisnya diuji menggunakan data citra sebanyak lima puluh buah citra yang telah diproses pada tahap sebelumnya. Pengujian dilakukan dalam dua mode yaitu mode verifikasi dan identifikasi. Dalam mode verifikasi menggunakan equal error rate (EER) dengan menghitung FNMR dan FMR dan dalam mode indetifikasi menggunakan correct recognition rate (CRR) berdasarkan persamaan yang dilakukan pada penelitian sebelumnya [Farouk, et al., 2010 ; Roy, et al., 2010].

CRR adalah Probabilitas identifikasi iris yang benar (Tabel 1.), EER adalah nilai titik potong FMR dengan FNMR atau tingkat kesalahan sama yaitu RMR=FNMR (Tabel 2.), FMR adalah probabilitas bahwa sistem menyatakan data uji yang tidak terdaftar dalam database dikenali atau cocok dengan data citra dalam database dan FNMR adalah probabilitas bahwa sistem menyatakan data uji yang terdaftar dalam database tidak dikenali atau tidak cocok dengan data citra dalam database.

Tabel 1. Perbandingan hasil CRR

\begin{tabular}{|l|c|}
\hline Algoritma & CRR (\%) \\
\hline Daugman, [1993] & 98,13 \\
\hline Harjoko, et al. [2009] & 84,25 \\
\hline Roy, et al., [2010] & 98,29 \\
\hline Peneliti & 99,98 \\
\hline
\end{tabular}

Tabel 2. Perbandingan hasil EER

\begin{tabular}{|l|c|}
\hline Algoritma & CRR (\%) \\
\hline Daugman, [1993] & 1.80 \\
\hline Harjoko, et al. [2009] & 0,28 \\
\hline Roy, et al., [2010] & 0.74 \\
\hline Peneliti & 0.44 \\
\hline
\end{tabular}

Berdasarkan hasil yang ditunjukkan pada Tabel 2 dan Tabel 3 menunjukkan bahwa algoritma yang diusulkan mencapai hasil
$\mathrm{CRR}=99,98$ dan $\mathrm{EER}=0.44$ yang menunjukkan bahwa kinerja algoritma yang diusulkan oleh peneliti sangat baik dan dapat digunakan dalam mode identifikasi maupun mode verifikasi.

\section{KESIMPULAN}

a. Metode yang dikembangkan mampu melakukan identifikasi seseorang berdasarkan citra irisnya.

b. Pendekatan identifikasi iris yang dilakukan dalam penelitian ini dapat melakukan identifikasi dengan hasil CRR $=99,98 \%$ dan $\mathrm{EER}=0,44$ dengan demikin metode ini dapat digunakan sebagai salah satu alternative untuk sistem identifikasi personal berdasarkan citra iris.

\section{PENGHARGAAN DAN TERIMA KASIH}

Penulis mengucapkan terima kasih kepada database CASIA [CASIA, 2006] yang telah memberikan dukungan data citra retinopati diabetes beserta data hasil pemeriksaan medis terhadap penelitian ini.

\section{PUSTAKA}

Chaudhary, U., Mubarak, M., C., Iris Recognition Using BPNN Algoritma, International Journal of Engineering Research and Applications (IJERA), National Conference on Emerging Trends in Engineering \& Technology (VNCET), Mar 2012, 203-208.

Chinese Academy of Sciences-Institute of Automation (CASIA), 2006, CASIA Iris Image Database, Juni 2004, http:// biometrics.idealtest.org/

Chowhan, S., S., Shinde, G., N., Iris Recognition Using Fuzzy Min-Max Neural Network, International Journal of Computer and Electrical Engineering, 2011, Vol. 3, No. 5, Oct 2011, 743-747 
Daugman, J., G., High Confidence Visual Recognition of Person by a Test of Statisticl Independece, IEE Trans. Pattern Analysis and Machine Intell, 1993, 15, 1148-1161.

--Daugman, J., How Iris Recognition Works, IEE ICIP, 2002, I-33 - I-36.

Dillak, R., Y., Bintiri, M., G., Identifikasi Fase Penyakit Retinopati Diabetes Menggunakan Jaringan Syaraf Tiruan Levenberg-Marquardt, Seminar Nasional Informatika (SEMNASIF), 2012 : C-110C-114.

Dillak, R., Y., Bintiri, M., G., Pangestuty, D., W., Pemanfaatan Algoritma Jaringan Syaraf Tiruan Levenberg-Marquardt Untuk Mendeteksi Penyakit Alzheimer, Seminar Nasional Informatika (SEMNASIF), 2012 : C-126-C-133.

Ezhilarasan, M., Jacthish, R., Subramanian, G., K., S., Umapathy, R., Iris Recognition Based On Its Texture Pattern, International Journal on Computer Science and Engineering (IJCSE), 2010, Vol. 2, No. 9, 3071-3074.

Farouk, R., M., Kumar, R., Riad, K., A., Iris Matching Using Multi-Dimensional Artificial Neural Network, The Iternational of Engineering and Technology, IET Computer Vision, 2011, Vol. 5, Iss. 3, 178-184.

Gadkari, D., Image Quality Analysis Using GLCM, Tesis, University of Central Florida, Florida, 2004.

Gonzales, R., C., Woods, R., E., Digital Image Processing, $3^{\text {rd }}$ ed., Prentice Hall : Upper Sadle River, NewJersey, USA, 2008.

Gopikrishnan, M., Santhanam, T., Improved Biometric Recognition and Identification of Human Iris Pattern Using Neural
Network, Journal of Theoretical and Applied Information Technology (JATIT), 2010, Vol. 31, No. 2, Sep 2011, 134-139.

Gopikrishnan, M., Santhanam, T., Effect of Different Neural Networks on The Accuracy in Iris Pattern Recognition, International Journal of Reviews in Computing (IJRIC), 2011, Vol. 7, Sep 2011, 22-28

Harjoko, A., Hartati, S., Dwiyasa, H., A Method for Iris Recognition Based on 1D Coiflet Wavelet, world Academy of Science,Enginnering and Technology, 2009, 126-129.

Hossain, Md., S., Sarma, K., K., Iris Recognition Based Identification Using 2D-Discrete Cosine Transform and Self Organising Map Neural Network, International Journal of Systems, Algorithm \& Application (IJSAA), 2012, Vol. 2, Issue ICRAET 12, May 2012, 2277-2677

Kayte, C., N., Pawar, V., P., Sonwane, C., D., Efficient Biometric for Human Identification and Verification through Iris Recognition, Indian Streams Reseacrh Journal, Vol. 1, Issue V, Jun 2012, 1-4.

Khan, Y., D., Ahmad, F., Anwar, M., W., A Neuro-Cognitive Approach for Iris Recognition Using Back Propagation, Worl Applied Sciences Journal, 2012, 678-685.

Kuivaleinen, M., Retinal Image Analysis Using Machinde Vision, Tesis, Departemen of Information Technoloy, Lappeenranta University of Technology, Lappeenranta, 2005.

Makthal, S., Analysis and Synthesis of Iris Images, Master's Dissertation, Department of Electrical Engineering, West Virginia University, USA, 2005. 


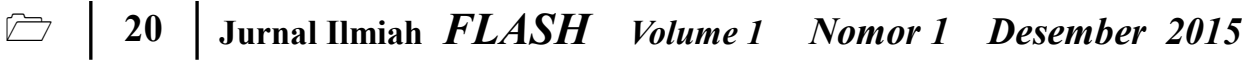

Mohamed, M., A., Abou-Elsoud, Eid, M., M., An Efficient Algorithm in Extracting Human Iris Morphological Features, IEEE International Conferences on Networking and Media Convergence (ICNM), 2009, 146-150.

Rashad, M., Z., Shams, M., Y., Nomir, O., ElAwady, R. M., Iris Recognition Based on LBP and Combine LVQ Classifier, International Journal od Computer Science \& Information Technology (IJCSIT), 2011, Vol. 3, No. 5, Oct 2011, 67-78

Roy, K., Recognition of Nonideal Iris Images Using Shape Cuided Approach and Game Theory, Thesis, The Department of Computer Science and Software Engineering, Concordia University, Motreal, Quebec, Canada, 2011.
Tiwari, U., Kelkar, D., Tiwari, A., Study of Defferent IRIS Recognition Methods, International Journal of Computer Technology and Electronics Engineerign (IJCTEE), 2012, Vol. 2, 76-81.

Vatsa, M., Singh, R., Noore, A., Improving Iris Recognition Performance Using Segmentation, Quality Enhancement, Match Score Fusion, and Indexing, IEEE Transactions On System, Man, and Cybernetics-Part B : Cybernetics, 2008.

Zhou, S., A Novel Approach to Iris Localization and Code Matching for Iris Recognition, Desertasi, Graduate School of Computer and Information Science Nova Southeastern University, 2009. 